\title{
Male Mate Choice in Mixed Bisexual/Unisexual Breeding Complexes of Poecilia (Teleostei: Poeciliidae)
}

\author{
Ingo Schlupp, Jakob Parzefall \& Manfred Schartl
}

Schlupp, I., Parzefall, J. \& SChartl, M. 1991: Male mate choice in mixed bisexual/unisexual breeding complexes of Poecilia (Teleostei: Poeciliidae). Ethology 88, 215-222.

\begin{abstract}
The livebearing all-female fish Poecilia formosa reproduces by gynogenesis, a modified form of parthenogenesis. $P$. formosa forms at least two breeding complexes: in its northern range it exists sympatrically with Poecilia latipinna and in its southern range with Poecilia mexicana. Differences between these complexes and their possible origin are discussed. Embryogenesis is triggered by sperm of males of these closely related sympatric species. Because inheritance is strictly maternal, from the male point of view energy and time invested are totally lost.

In this study we wanted to elucidate whether males are able to distinguish between conspecific and parasitic females. It could be shown that males are able to distinguish females optically, but that this ability was obscured as soon as chemical and/or tactile contact was possible.

Furthermore, we found that females in an attractive phase of their sexual cycle are always preferred, regardless of species. This is possibly the mechanism by which parasitic females obtain the matings they need to reproduce.
\end{abstract}

Corresponding author: INGO SCHLUPP, Zoologisches Institut und Zoologisches Museum der Universität Hamburg, Martin Luther King Platz 3, W-2000 Hamburg 13, F.R.G.

\section{Introduction}

The Amazon molly (Poecilia formosa [GIRARD 1859]) - a small unisexual poeciliid of presumed hybrid origin (HuBBs \& HuBBs 1932; TuRner 1982) - is part of a unique mating system, occurring naturally in the rivers and coastal lagoons of southeastern Texas and northeastern Mexico.

$P$. formosa is in general an all-female fish. Its reproductive mode is gynogenesis (HuBbs \& HubBs 1932, 1946). Gynogenesis is a modified form of parthenogenesis, where females produce diploid eggs, but are still dependent on 
sperm to trigger embryogenesis. Sperm is delivered by males of Poecilia mexicana Steindachner, 1863 or Poecilia latipinna (Le Sueur, 1821). These closely related species exist sympatrically with $P$. formosa- $P$. latipinna in Texas and $P$. mexicana in Mexico. These species are also the presumed parental species (HubBs \& HubBs 1932; TURNER 1982). Fertilization is internal. Usually no genetic material of the male is transmitted, inheritance is maternal. This, and high clonal diversity has been demonstrated by several studies, using different techniques (HuBBs \& HUBBS 1946; Kallman 1962 a, b; Turner et al. 1980), and most recently by DNAfingerprinting (SCHARTL et al. 1990; TURNER et al. 1990).

Only very rarely are triploids produced (SCHULTZ \& KaLLMAN 1968; RASCH et al. 1970; RASCH \& Balsano 1989; Balsano et al. 1989). They contain one paternal set of chromosomes and two maternal sets.

Even more exceptional seems to be an introgression of male genes (HASKINS et al. 1960; BAISANO et al. 1989; RASCH \& BALSANO 1989). Introgression is a rare deviation from matroclinous reproduction, where parts of the male genome, like the genes for black spotting, apparently are incorporated into the female genome.

From the male point of view the energy and time invested into production of sperm, courtship etc. are totally lost. Additionally, the risk of predation is taken in vain. It seems reasonable to assume a selection pressure, that forces males to discriminate conspecific ( $P$. latipinna or P. mexicana) and parasitic ( $P$. formosa) females (KAWECKI 1988). Male choice has been demonstrated in the $P$. formosal P. latipinna complex (HubBs 1964; WoOdHEAD \& ARMSTRONG 1985) but seemed to be absent in the $P$. formosa/P. mexicana complex (Balsano et al. 1981, 1985). The two complexes will be treated separately because of the obvious differences between them.

The absence of choice, however, does not necessarily mean that males are unable to distinguish between conspecifics and heterospecifics.

The aim of our present study was to elucidate male ability to choose, a possibly related mechanism, and the role of male choice in the $P$. formosal P. mexicana complex.

\section{Material and Methods}

Laboratory stocks of $P$. formosa, P. latipinna and $P$. mexicana were used in this study. All stocks were maintained in our laboratories in Munich or Hamburg for several generations. $P$. formosa were bred with ornamental black molly males (MMmm). Black mollies are a black form of P. mexicana and P. latipinna.

P. formosa originated from an old stock, going back to a collection by HASKINS in Brownsville (Texas) in 1953. P. mexicana were collected repeatedly in the Arroyo de Solpho near Tapijulapa, Tabasco, Mexico, from an allopatric population. The $P$. latipinna originate from sympatric populations in Texas.

Three experiments were designed: the first one to test whether species recognition is controlled by visual cues, the second and third one to evaluate the role of chemical cues.

All pairs of females were of equal total length $( \pm 1 \mathrm{~mm})$.

Female poeciliids show a marked sexual cycle (PARzEFall 1973). During a $2-$ to $3-d$ period they are extremely attractive to males. This happens immediately after they have given birth.

In the first and second experiment females were not attractive, in the third one, one of the females was attractive. Nonparametric statistical tests were used (SrEgEL 1956). All p-values are two tailed. 
Experiment 1: For this choice experiment a 25-1 aquarium was divided into 3 equal sections by glass partitions. No water flow was possible between sections, therefore no chemical information could be exchanged. The middle section was divided into 2 sections $(A, B)$ by a line drawn on the front (Fig. 2). The test males were placed in the middle compartment and remained there until the experiment was over. The females were kept in $8-1$ aquaria and introduced into the side sections immediately before a trial. Visual contact was inhibited for $5 \mathrm{~min}$ by additional opaque partitions. $1 \mathrm{~min}$ after removing these partitions, the time males spent on each side was recorded for 3 min. For control of side preferences females were shifted.
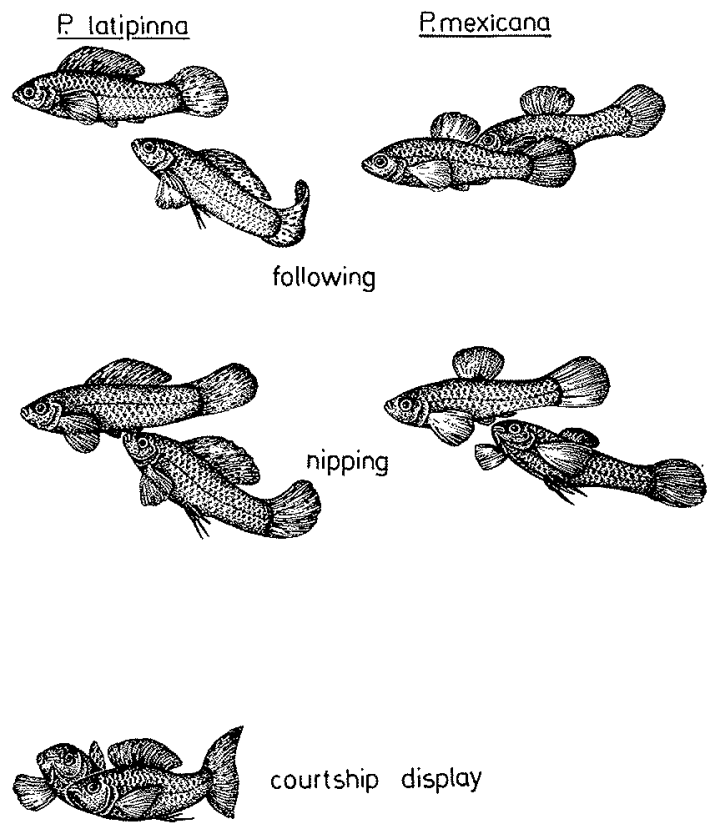

Fig. 1: Behaviour patterns of Poecilia mexicana and Poecilia latipinna
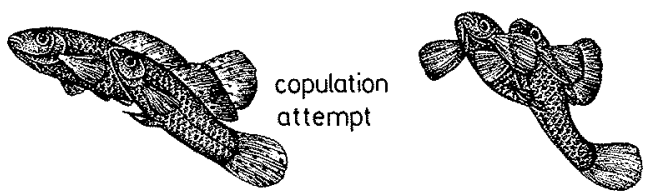

Experiment 2: In the second experiment males were allowed to have chemical and tactile contact with the females. The females of the first experiment were introduced simultaneously into the middle section. Male behaviour was recorded for $10 \mathrm{~min}$. Recorded behaviour was: time spent in close contact with a female, following, nipping and copulation attempts (Fig. 1), as described by PARZEFALL (1969). Some of the females were experienced, some virgin.

Experiment 3: In the third experiment, either a conspecific or a $P$. formosa female was attractive (PARZEFALL 1973). We tested both attractive conspecifics against unattractive $P$. formosa and attractive $P$. formosa against unattractive conspecifics. The two females and one male were placed into a 50-1 tank. They were allowed to acclimatize for $30 \mathrm{~min}$. Then the time males spent in close contact with each female was recorded for $10 \mathrm{~min}$. 


\section{Results}

Experiment 1: In the first experiment only visual information was available for the males. Males spent significantly more time with the conspecific female (Wilcoxon matched pairs signed rank test, $\mathrm{z}=2.35, \mathrm{p}<0.05, \mathrm{n}=20$; Fig. 2).

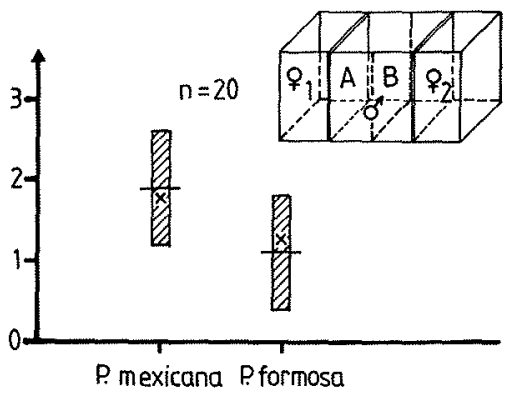

Fig. 2: Descriptive statistics of Exp. 1: time (min) spent with females $(\bar{x}[-] \pm 1 \mathrm{SD}, \tilde{\mathrm{x}}[\mathrm{x}])$ and experimental tank for Exp. 1 and 2

Experiment 2: When chemical and tactile contact was allowed, no significant preferences were shown (Wilcoxon matched pairs signed rank tests, $n s, n=19$; Fig. 3). It is noteworthy that conspecific females gain slightly more overall attention, but fewer copulation attempts.

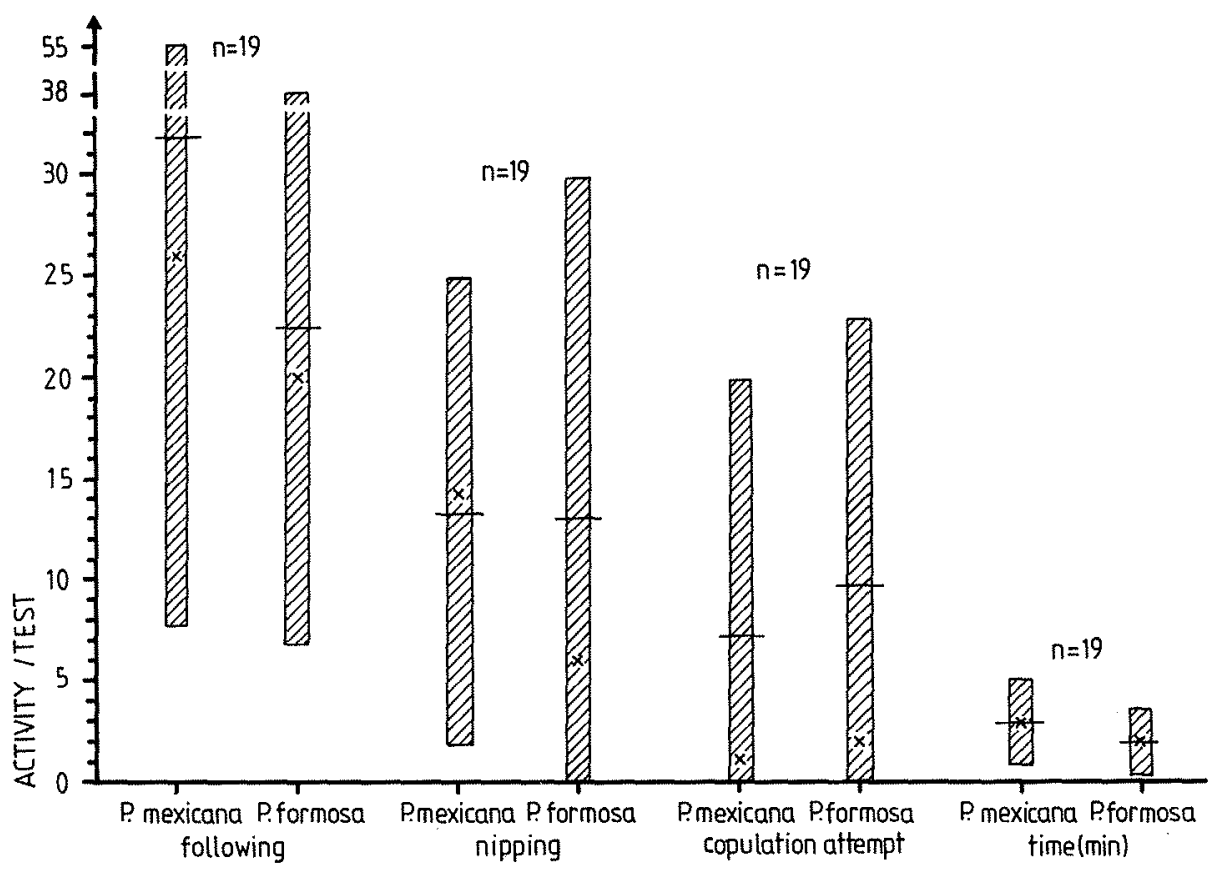

Fig. 3: Descriptive statistics of Exp. 2: male behaviour $(\tilde{x}[-] \pm 1 \mathrm{SD}, \tilde{\mathrm{x}}[\mathrm{x}])$ : in following, nipping and copulation attempts single actions were counted, in time, time spent in close contact with a female was recorded 

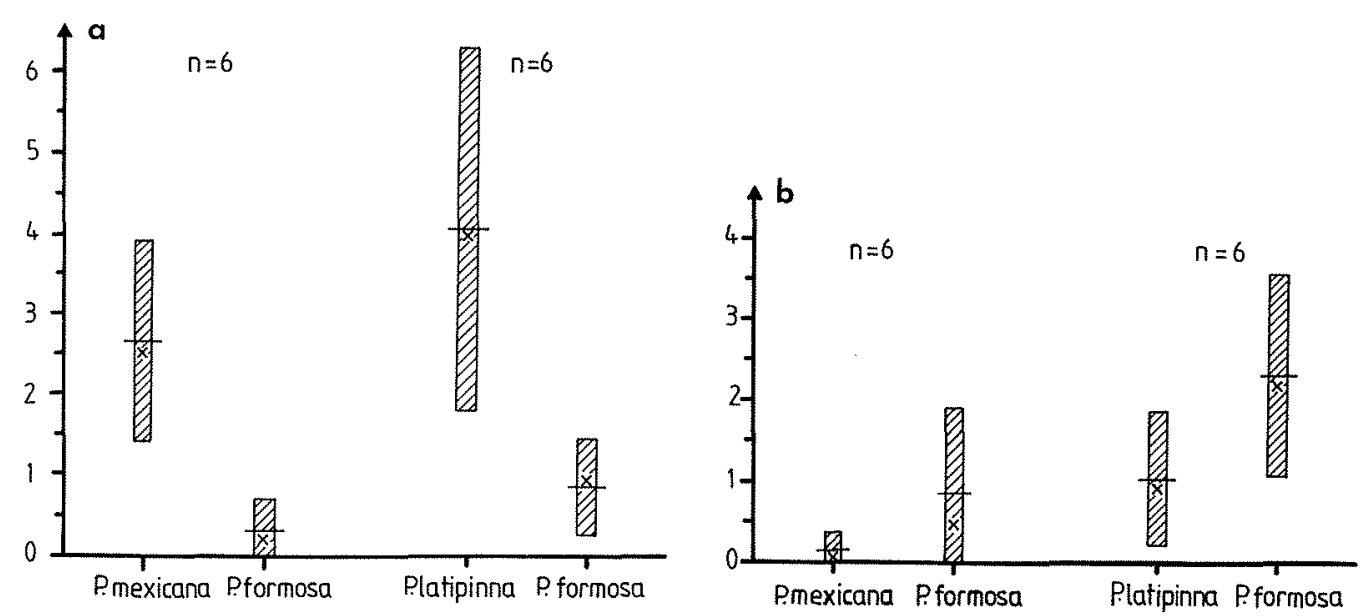

Fig. 4: Descriptive statistics of Exp. 3: time (min) spent with females ( $\bar{x}[-] \pm 1 \mathrm{SD}, \tilde{\mathrm{x}}[\mathrm{x}])$; a: conspecifics are attractive; $b$ : heterospecifics are attractive

In the same experiment males did not distinguish between virgin and experienced $P$. formosa females (Mann Whitney $U$ tests, $n s, n=19$ ), with one interesting exception: experienced $P$. formosa females were preferred in copulation attempts (Mann Whitney $U$ test, $z=2.88, p<0.005, \mathrm{n}=19$ ).

Experiment 3: If an attractive female was available, it was always preferred, regardless of species. Males always spent significantly more time with the attractive female (Wilcoxon matched pairs signed rank tests, all $\mathrm{p}<0.05, \mathrm{n}=6$ each, Fig. 4 a, b). This was true for P. mexicana and for P. latipinna males.

In the second and third experiment females of $P$. formosa were observed disturbing matings of $P$. mexicana actively. After intercepting they sometimes offered themselves immediately to the male. This active female behaviour occurred in 5 out of 20 trials in Exp. $2(25 \%)$. In 3 out of $20(15 \%)$ cases the $P$. mexicana female was chased away from the male by the $P$. formosa female. The same behaviour is shown by $P$. formosa against $P$. latipinna both in the laboratory (RYAN, pers. comm.) and in the field (SCHLUPP, unpubl.).

This is a very unusual behaviour pattern for females and probably adaptive in competition with females of the host species.

\section{Discussion}

The ability of $P$. mexicana males to discriminate between conspecific and heterospecific females, when only visual cues were allowed (Exp. 1), indicates that even allopatric males can distinguish between the species involved.

The fact that this ability is obscured as soon as chemical and/or tactile cues are used (Exp. 2), suggests that $P$. formosa females have evolved a mechanism to thwart male species recognition ability. 
The result of Exp. 3 indicates that a chemical signal, perhaps a pheromone (CONSTANTZ 1989), released by the females at least during the period of attractiveness (PARZefall 1973; Zeiske 1968, 1971), triggers male behaviour. It is however surprising that this signal is strong enough to override species recognition. The importance of chemical signals for species and mate recognition in this genus is well documented (e. g. Liley 1966; Gandolfi 1969; Crow \& Liley 1979; MEYer \& Liley 1982), especially in P. mexicana (ZeIske 1968, 1971; Parzefall 1969, $1970,1973)$. It is important to note that this signal is not the same in the whole family Poeciliidae. PARzefall (1973) showed that males of $P$. mexicana do not respond to attractive females of Xiphophorus helleri. It seems possible that the same signal is shared by the genus Poecilia only. Investigations concerning this question are underway.

These results, however, are somewhat preliminary. Sample size is rather small and effects of population, experience, age and rank position must be subjected to further investigation.

The described mechanism is possibly the mechanism by which the parasitic $P$. formosa females obtain matings in nature.

Another study of male mate choice in the $P$. formosa/P. mexicana complex showed that even sympatric males do not prefer conspecific females significantly, if contact is allowed (BALSANO et al. 1981, 1985). This is confirmed by our results.

In the $P$. formosa/P. latipinna complex the situation seems to be different. HubBs (1964), WOODHEAD \& ARMSTRONG (1985) and RYAN (unpubl.) found male preference for conspecific females in sympatric as well as in allopatric populations and in laboratory stocks. In the sympatric populations of $P$. latipinna we used, this preference is reversed by attractiveness of the parasitic $P$. formosa.

The described active mating behaviour of $P$. formosa females is uncommon in the genus. It increases the probability of attracting male attention and mating attempts. This might be the reason that $P$. formosa females get more copulation attempts, whereas all other behaviour is more often directed at conspecifics (Fig. 3). This is also reflected by male preference for experienced $P$. formosa.

Aggression between the two types of females indicates that competition for males is existent, although BALSANO et al. (1985) found that males are not a limited resource. However, females of $P$. formosa adopted several tactics to achieve male attention, whereas females of $P$. mexicana and $P$. latipinna remain passive.

We seem to be looking at an evolutionary arms race and so far $P$. formosa females seem to be winning.

A completely different explanation for the obvious differences between the $P$. formosa/P. mexicana and $P$. formosa/P. latipinna complexes is to assume that a measurable contribution of $P$. mexicana males to the genome of the offspring exists which is correlated to their mating efforts.

Most important is the chance of fathering a triploid clone. This may be a rare event, but if it happens, the genes are perpetuated extremely efficiently, because the haploid male genome is perpetuated as an entity. It fits into this hypothesis that the probability of fathering a triploid clone is much higher for $P$. mexicana males: most triploid clones are known from the $P$. formosalP. mexicana complex, whereas hardly any triploid clones were reported from the $P$. formosa/P. latipinna 
complex (BALSANO et al. 1989). Apparently males of P. mexicana are more successful in overcoming the female mechanism of exclusion of the male genome. Fathering a triploid clone is clearly not adaptive within the $P$. mexicana gene pool. But it increases fitness on the level of genes. This also applies to other elevations of ploidy within unisexual complexes. However, these genes, especially the genes affecting male mating behaviour, will not be expressed in an allfemale fish. Usually this is thought to be connected with fast degeneration of genes by mutation ("Muller's ratchet" [MulLER 1964]). At least in P. formosa this is apparently not true, as demonstrated by hormonally induced males, which are typical males in morphology and behaviour (SCHARTL et al., in press). The genes for all investigated male traits are complete and intact.

A considerable payoff for males may therefore be an important factor in the evolution of male mate choice in the $P$. formosal $P$. mexicana complex.

\section{Acknowledgements}

We thank M. J. RYAN, Austin, for his permission to use his unpublished data. We thank M. IRENTSCHIUK, W. KAMBACH, A. SCHLUPP and D. TEEGE for technical assistance and animal care and M. HÄNEL for drawing the figures. A. EGGERS, Hamburg and an anonymous referee made helpful suggestions on the manuscript.

\section{Literature Cited}

Balsano, J. S., Kucharski, K., Randle, E. J. \& Monaco, P. J. 1981: Reduction of competition between bisexual and unisexual females of Poecilia in northeastern Mexico. Env. Biol. Fish 6, $39-48$.

- -, Randle, E. J., Rasch, E. M. \& Monaco, P. J. 1985: Reproductive behavior and the maintenance of all-female Poecilia. Env. Biol. Fish 12, 251-263.

- -, Rasch, E. M. \& Monaco, P. J. 1989: The evolutionary ecology of Poecilia formosa and its triploid associate. In: Ecology and Evolution of Livebearing Fishes (Poeciliidae). (MeEfe, G. K. \& SNELSON, F. F. jr., eds.) Prentice Hall, New Jersey, pp. 277-298.

CONSTANTZ, G. D. 1989: Reproductive biology of poeciliid fishes. In: Ecology and Evolution of Livebearing Fishes (Poeciliidae). (MeEFE, G. K. \& SNelson, F. F. jr., eds.) Prentice Hall, New Jersey, pp. 33-50.

Crow, R. T. \& LILEY, N. R. 1979: A sexual pheromone in the guppy, Poecilia reticulata (Peters). Can. J. Zool. 57, 184-188.

Gandolfi, G. 1969: A chemical sex attractant in the guppy Poecilia reticulata Peters (Pisces, Poeciliidae). Monitore Zool. Ital. (N.S.) 3, 89-98.

Haskins, C. P., Haskins, E. F. \& HewitT, R. E. 1960: Pseudogamy as an evolutionary factor in the poeciliid fish Mollienesia formosa. Evolution 14, 473-483.

HuBBS, C. L. \& HUBBS, L. C. 1932: Apparent parthenogenesis in nature in a form of fish of hybrid origin. Science $76,628-630$.

- $-8 x-1946$ : Breeding experiments with the invariably female, strictly matroclinous fish, Mollienesia formosa. Genetics 31, 218.

HuBbS, C. 1964: Interactions between bisexual fish species and its gynogenetic sexual parasite. Bull. Tex. Mem. Mus. 8, 1-72.

Kallman, K. D. $1962 \mathrm{a}$ : Population genetics of the gynogenetic teleost Mollienesia formosa (Girard). Evolution 16, 497-504.

- 1962b: Gynogenesis in the teleost Mollienesia formosa, with a discussion of the detection of parthenogenesis in vertebrates by tissue transplantation. J. Genet. 58, 7-21. 
KAWECKI, T. J. 1988: Unisexual/bisexual breeding complexes in Poeciliidae: why do males copulate with unisexual females? Evolution 42, $1018-1023$.

LILEY, N. R. 1966: Ethological isolating mechanisms in four sympatric species of poeciliid fishes. Behav. Suppl. 13.

MEYER, J. H. \& LILEY, N. R. 1982: The control of a sexual pheromone in the female guppy, Poecilia reticulata. Can. J. Zool. 60, 1505-1510.

MULLER, H. J. 1964: The relation of recombination to mutational advance. Mutat. Res. 1, 2-9.

PARZEFALl, J. 1969: Zur vergleichenden Ethologie verschiedener Mollienesia-Arten einschließlich einer Höhlenform von $M$. sphenops. Behaviour 33, 1-37.

- 1970: Morphologische Untersuchungen an einer Höhlenform von Mollienesia sphenops (Pisces, Poeciliidae). Z. Morphol. Tiere 68, 323-342.

- - 1973: Attraction and sexual cycle of poeciliids. In: Genetics and Mutagenesis of Fish. (SCHRÖDER, J. H., ed.) Springer Verlag Berlin, pp. 177-183.

RASCH, E. M. \& BALSANO, J. S. 1989: Trihybrids related to the unisexual molly fish, Poecilia formosa. In: Evolution and Ecology of Unisexual Vertebrates. (DAwLEY, R. M. \& BOGART, J. P., eds.) Bull. 466 New York State Mus. Albany, New York, pp. 252-267.

- -, PREHN, L. M. \& RASCH, R. M. 1970: Cytogenetic studies of Poecilia (Pisces): II. Triploidy and DNA levels in naturally occurring populations associated with the gynogenetic teleost Poecilia formosa (Girard). Chromosoma, Berl. 31, 18-40.

Schartl, M., Nanda, I., Schlupp, I., Parzefall, J., Schmid, M. \& Epplen, J. T. 1990: Genetic variation in the clonal vertebrate Poecilia formosa is limited to few truly hypervariable loci. Fingerprint News 2, 22-24.

- -, Schlupp, I., Schartl, A., Meyer, M. K., Nanda, I., Schmid, M., Epplen, J. T. \& Parzefall, J.: On the stability of dispensable constituents of the eucaryotic genome: Stability of coding sequences versus truly hypervariable sequences in a clonal vertebrate, the Amazon molly, Poecilia formosa. Proc. Natl. Acad. Sci. U.S.A., in press.

SCHuLtZ, R. J. \& Kallman, K. D. 1968: Triploid hybrids between the all-female teleost Poecilia formosa and Poecilia sphenops. Nature 219, 280-282.

SIEGEL, S. 1956: Nonparametric Statistics for the Behavioral Sciences. McGraw Hill, New York.

TURNer, B. J. 1982: The evolutionary genetics of a unisexual fish, Poecilia formosa. In: Mechanisms of Speciation. (Barigozzi, C., ed.) Alan R. Liss, New York, pp. 265-305.

- -, BRETT, B.-L. H. \& MILLER, R. R. 1980: Interspecific hybridization and evolutionary origin of a gynogenetic fish, Poecilia formosa. Evolution 34, 917-922.

- -, Elder jr., J. F., Laughlin, T. F. \& Davis, W. P. 1990: Genetic variation in clonal vertebrates detected by simple-sequence DNA fingerprinting. Proc. Natl. Acad. Sci. U.S.A. $87,5653-5657$.

WoOdHEAd, A. D. \& ARMstrong, N. 1985: Aspects of the mating behavior of male mollies (Poecilia spp.). J. Fish Biol. 27, 593-601.

ZEISKE, E. 1968: Prädispositionen bei Mollienesia sphenops (Pisces, Poeciliidae) für einen Übergang zum Leben in subterranen Gewässern. Z. vergl. Phys. 58, 190-222.

- - 1971: Ethologische Mechanismen als Voraussetzung für einen Übergang zum Höhlenleben. Untersuchungen an Kaspar-Hauser-Männchen von Poecilia sphenops (Pisces, Poecilidae). forma et functio 4, 387-393.

Received: February 7, 1991

Accepted: May 17, 1991 (W. Pflumm) 